\title{
ACRL Candidates, 1977 Elections
}

\section{VICE-PRESIDENT/PRESIDENT-ELECT}

Evan Ira Farber, Librarian, Earlham College, Richmond, Indiana

Arthur Monke, Librarian, Bowdoin College, Brunswick, Maine

\section{DIRECTORS-AT-LARGE}

Marjorie C. Dennin, Director of Learning Resources, Northern Virginia Community College, Annandale Campus, Annandale, Virginia

Hal C. Stone, Assistant Dean, Instructional Resources, Los Angeles City College, Los Angeles, California

William J. Studer, Associate Dean of University Libraries, Indiana University, Bloomington, Indiana

Billy R. Wilkinson, Staff Relations Officer, The New York Public Library, New York, New York

\section{AGRICULTURE AND BIOLOGICAL SCIENCES SECTION}

\section{Vice-Chairman/Chairman-Elect}

David K. Oyler, University Librarian, Humboldt State University, Arcata, California

Linnea Sodergren, Health Manpower Specialist, Department of Health, Education and Welfare, Public Health Service, Health Manpower Branch, Chicago, Illinois

Secretary

Vladimir Micuda, Life Sciences Librarian, Pennsylvania State University, University Park, Pennsylvania

Linda L. Phillips, Librarian, Agricultural Technical Institute, The Ohio State University, Wooster, Ohio

\section{ANTHROPOLOGY SECTION}

Vice-Chairman/Chairman-Elect

David L. Perkins, Head Bibliographer, California State University, Northridge, Northridge, California

Suzy M. Slavin, Assistant Head, Reference

\section{Attention}

All future news items should be sent to: John V. Crowley, James M. Milne Library, State University College, Oneonta, New York 13820.

Please draw this information to the attention of your colleagues and of your personnel officers and newsletter editors.
Department, McLennan Library, McGill University, Montreal, Quebec, Canada

Secretary

Elizabeth J. Airth, Reference Librarian and HRAF Supervisor, Reference Department, General Libraries, University of Texas at Austin, Austin, Texas

Patricia Ann White, Reference Librarian, Michigan State University Libraries, East Lansing, Michigan

Member-at-Large

M. Sangster Parrott, Assistant Professor, Library Science/Educational Technology, School of Education, University of North Carolina at Greensboro, Greensboro, North Carolina

Patricia W. Silvernail, Assistant Professor, College of Staten Island Library, Staten Island, New York

\section{ART SECTION}

\section{Vice-Chairman/Chairman-Elect}

Karen Esper, Materials Selector for Humanities, Case Western Reserve University Libraries, Cleveland, Ohio

Rosella L. Ferster, Art Cataloger, Duke University, Durham, North Carolina

Betty Jo Irvine, Fine Arts Librarian, Fine Arts Library, Indiana University, Bloomington, Indiana

Secretary

James R. Burch, Assistant Head, Environmental Design Library, University of California, Berkeley, California

Karen Muller, 1110 Grove Street, Evanston, Illinois

\section{ASIAN AND AFRICAN SECTION}

Vice-Chairman/Chairman-Elect

Corinne Nyquist, Director, World Study Center, Sojourner Truth Library, State University College, New Paltz, New York

Hans E. Panofsky, Curator of Africana, Northwestern University Library, Evanston, Illinois

Member-at-Large

Hideo Kaneko, Curator, East Asian Collection, Yale University Library, New Haven, Connecticut

Elizabeth A. Widenmann, African Bibliographer and Cataloger, Columbia University Libraries, New York, New York

\section{COLLEGE LIBRARIES SECTION}

\section{Vice-Chairman/Chairman-Elect}

Dale K. Carrison, Executive Director, Mankato State College Library, Mankato, Minnesota 
Gertrude C. Davis, Head Librarian, Martha S. Grafton Library, Mary Baldwin College, Staunton, Virginia

Secretary

Joel M. Lee, Head of Technical Services, Donnelley Library, Lake Forest College, Lake Forest, Illinois

Brother Paul J. Ostendorf, Head Librarian, Fitzgerald Library, Saint Mary's College, Winona, Minnesota

\section{COMMUNITY AND JUNIOR COLLEGE LIBRARIES SECTION}

\section{Vice-Chairman/Chairman-Elect}

Imogene I. Book, Director of the Library, Rend Lake College, Ina, Illinois

Bob Schremser, Head Librarian, Alexander City State Junior College, Alexander City, Alabama

\section{Secretary}

William I. Bunnell, Director of Library Services, County College of Morris, Dover, New Jersey

Raymond G. Roney, Director of the Library, Washington Technical Institute, Washington, D.C.

\section{EDUCATION AND BEHAVIORAL SCIENCES SECTION}

Vice-Chairman/Chairman-Elect

Darrell Jenkins, Assistant Serials Librarian, New Mexico State University, Las Cruces, New Mexico
Jean C. Jones, Librarian, American Psychiatric Museum Association, Washington, D.C.

Secretary

Leslie Benton Bjorncrantz, Curriculum Librarian and Reference Librarian, Northwestern University, Evanston, Illinois

Marjorie Zumstein, Education and Psychology Librarian, Purdue University, West Lafayette, Indiana

\section{LAW AND POLITICAL SCIENCE SECTION}

\section{Vice-Chairman/Chairman-Elect}

Susan C. Finsen, Assistant Executive Officer, Congressional Research Service, Library of Congress, Washington, D.C.

Myron Jacobstein, Law Librarian, Stanford University Law Library, Stanford, California Member-at-Large

Frances Hunt Hall, Law Librarian and Associate Professor, Law Library, Southern Methodist University, Dallas, Texas

Leslie W. Sheridan, Director of University Libraries, The University of Toledo, Toledo, Ohio

\section{RARE BOOKS AND MANUSCRIPTS SECTION}

Vice-Chairman/Chairman-Elect

Evert Volkersz, Head, Department of Special Collections, State University of New York at Continued on page 320

\section{News From the Chapters}

The Eastern New York Chapter of ACRL held its fall meeting at the State University of New York at Cortland on October 1, 1976.

The meeting consisted of seven roundtable discussions which were available in both morning and afternoon sessions. The group leaders were drawn from the chapter, thus providing an opportunity for the membership to utilize its expertise in various areas of librarianship.

The topics discussed were "Minicomputers in Libraries," led by.John Linford, State University of New York at Albany; "Library Instruction," Lynn Case and Jon Lindgren, St. Lawrence University, Canton, New York; "Public Relations and Orientation," Jacquelyn Gavryck, SUNY, Albany; "Which Services and to Whom," Irving Stephens, Rensselaer Polytech- nic Institute, Troy, New York; "Weeding Library Collections," Mina LaCroix and Barbara Rice, SUNY, Albany; "Budgeting for Library Acquisitions," Sue Weaver, St. Lawrence University; and "Interlibrary Loan," Lee Dalzell, Williams College, Williamstown, Massachusetts.

Comments solicited on a questionnaire distributed by the Program Planning Committee indicate that the informal nature of the program was conducive to productive group discussion and that the format should be repeated next year.

Evaluative interviewing will be the subject of the spring meeting to be held at Williams College on May 26, 1977. Sheila Creth of the University of Connecticut, Storrs, will be the featured speaker. 


\section{Three timely reports on litorary systems from"the authority"}

\section{Automated Circulation Control Systems: An Overview of Com- mercially Vended Systems}

An extensive discussion by Barbara Evans Markuson of the characteristics of five circulation control systems, including CLSI, Checkpoint/Plessey, and Check-A-Book. In the July \& September 1975 issues of LTR. \$35.

\section{Microform Catalog Data Retrieval Systems}

A comparison of Information Design, Information Dynamics, and Library Processing Systems. In the May 1975 issue of LTR. $\$ 20$.

\section{Theft Detection Systems for Libraries}

A revealing and valuable 98 -page survey of manufacturers and users. In the May 1974 issue of LTR. $\$ 20$.

Library Technology Reports (LTR) is a unique bimonthly publication of the American Library Association that provides critical evaluations of products used in libraries, media centers, schools, and other educational institutions. Its purpose is twofold: to enable librarians and educators to make economical purchase decisions and to alert manufacturers of library needs and standards of performance expected.

To order any of the above individual issues or for additional information on the complete subscription service, write to:

LIBRARY TECHNOLOGY REPORTS American Library Association 50 East Huron Street Chicago, Illinois 60611

\section{ACRL Candidates}

Continued from page 303

Stony Brook, Stony Brook, New York

Marjorie Gray Wynne, Edwin J. Beinecke Research Librarian, The Beinecke Rare Book and Manuscript Library, Yale University, New Haven, Connecticut

Secretary

Thomas D. Burney, Assistant to the Chief, Rare Book and Special Collections Division, Library of Congress, Washington, D.C.

Maud D. Cole, Keeper of Rare Books, The New York Public Library, New York, New York

Member-at-Large

Elizabeth A. Swaim, Special Collections Librarian and University Archivist, Wesleyan University, Middletown, Connecticut

Liana Van Der Bellen, Chief, Rare Books and Manuscripts Division, National Library of Canada, Ottawa, Ontario, Canada

\section{SLAVIC AND EAST EUROPEAN SECTION}

Vice-Chairman/Chairman-Elect

Stan Humenuk, Head Catalog Librarian, Western Illinois University, Macomb, Illinois

Andrew L. Makuch, Bibliographer for Collection Development, University of Arizona Library, Tucson, Arizona

Member-at-Large

Marianna Tax Choldin, Slavic Bibliographer and Associate Professor of Library Administration, University of Illinois at Urbana-Champaign, Urbana, Illinois

Douglas K. Freeman, Slavic Cataloger/ SOLINET Coordinator, University of Tennessee Library, Knoxville, Tennessee

\section{UNIVERSITY LIBRARIES SECTION}

Vice-Chairman/Chairman-Elect

James T. Dodson, Director of Libraries, The University of Texas at Dallas, Richardson, Texas

James F. Wyatt, Dean of Libraries, The University of Alabama, University, Alabama

\section{SOLAR ENERGY DIGEST}

The unique, illustrated, monthly newsletter which makes the worldwide blizzard of news on all facets of solar energy conversion understandable to your readers. Send for a free copy and be convinced!

SOLAR ENERGY DIGEST

5644-0 Kearny Mesa Road

P.O. Box 17776AL, San Diego, CA 92117 


\section{american libraries}
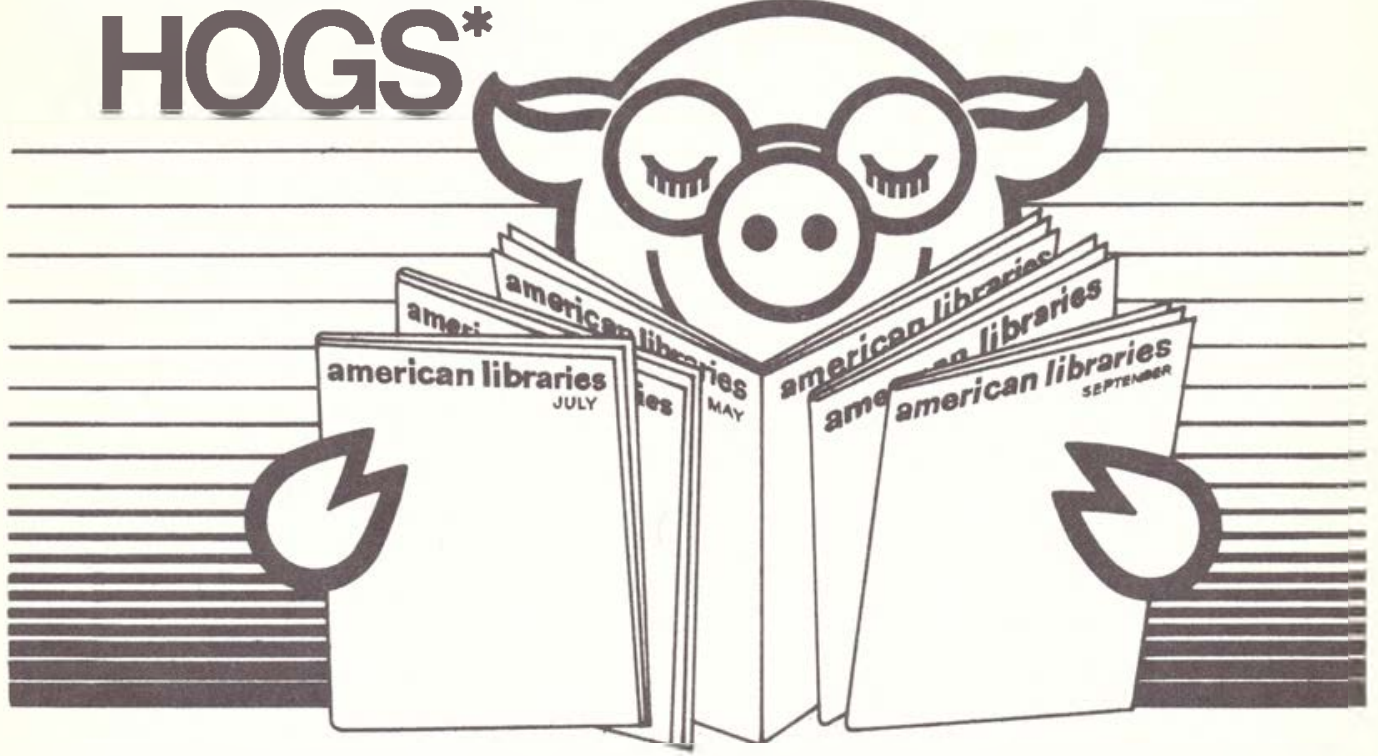

\section{Outfox them with copies for everyone}

There are several common breeds: the administrator who delays passing along the copy of american libraries that comes with the library's ALA membership...the staff member who takes the route-slip copy along on vacation to the Costa del Sow ... the ALA personal member who receives a copy at home and goes around with a smug, all-knowing expression.

You can't blame them for hogging american libraries. It's so filled with useful information that reading it takes time.

The solution is to oink for one or more additional subscriptions at $\$ 20$ a year. (Libraries that don't belong to the ALA can now keep up with the field by subscribing directly to american libraries at the same price.)

More than ever, american libraries keeps all library personnel in the mainstream of the library profession. It makes them more effective in their jobs.

Consider "The Source"- a major section of the magazine that delivers more up-to-the-minute and useful library news in one place than you can find anywhere else. It's filled with reports on official actions, successful programs, things to write for, how to get jobs, educational opportunities, media, technical breakthroughs and other valuable data too important and too timely to be withheld by delay in routing.

And there's the new "Action Line" department that tackles readers' most urgent library questions - another example of the magazine's new emphasis on information and service to working librarians.

Send in the coupon today and you'll soon be able to hog your own american libraries with a clear conscience.

("No offense intended to such library celebrities as Piglet, Wilbur, Hen Wen or the Empress of Blandings.)

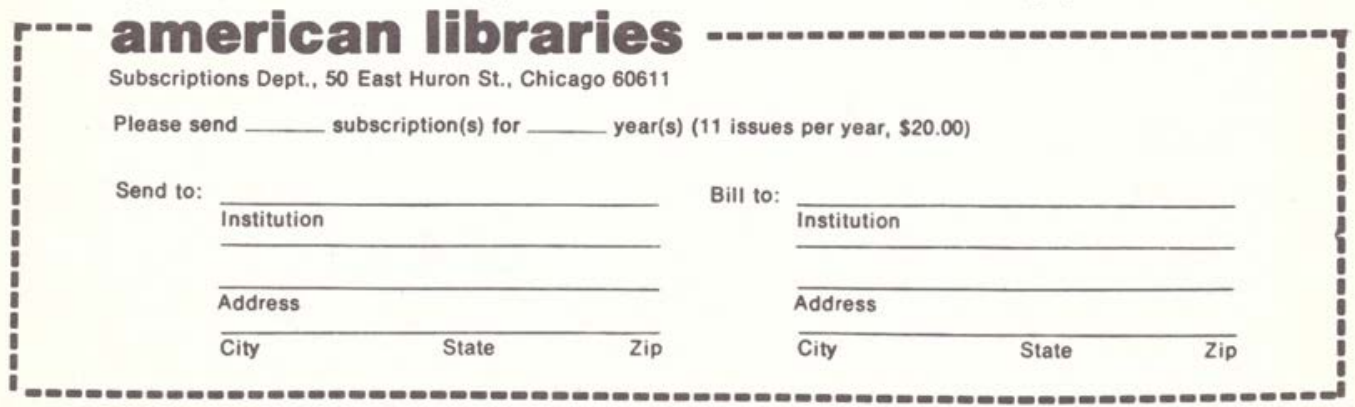




\section{For Your Computer and Information Scien 'a Collection}

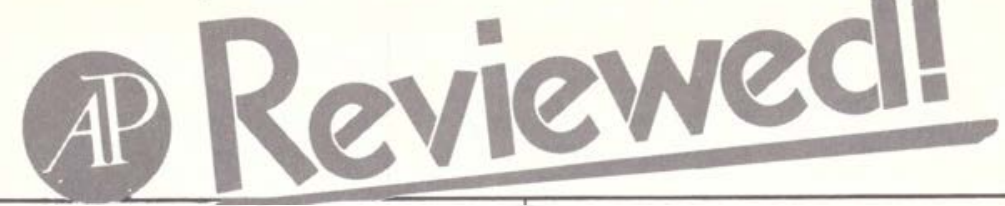

\section{Foundations of Microprogramming}

Architecture, Software, and Applications

by ASHOK K. AGRAWALA and TOMLINSON G. RAUSCHER

\section{A Volume in the ACM MONOGRAPH Series}

"Agrawala and Rauscher present a fine survey of the current status of microprogramming. The well-written introductory chapters provide a framework for detailed analysis of the architecture and the vertical, horizontal, and diagonal microprogramming of thirteen existing computers.

Chapters on microprogramming languages, applications, and suggested areas for further research complete their well-conceived effort. The book is remarkably readable, considering the dryness of the material in the detailed examples... this volume belongs in any library used by undergraduate or graduate students interested in computer science." —Choice, September 1976

1976, 416 pp., $\$ 15.50 / £ 11.00$

ISBN: 0-12-045150-6

\section{Computer Chess}

by MONROE NEWBORN

A Volume in the ACM MONOGRAPH Series

"Making digital computers play chess is a fascinating and challenging programming problem. Newborn's book begins by reviewing the history of computer chess-from early contributions by von Neumann, Shannon, and Turing to the ongoing work of current practitioners. The historical material is interwoven with the basic ideas used to implement the chess program algorithms. Most of the remaining chapters describe specific programs and some of the games in which they were used. . . Citing many references throughout and containing a short index, this book may be enjoyed by any chess player interested in how computers play the game and by others curious about how computers may be programmed for this purpose."-Choice, December 1975

1975,200 pp., $\$ 15.00 / £ 10.65$

ISBN: $0-12-517250-8$

\section{Information for Action}

From Knowledge to Wisdom

edited by MANFRED KOCHEN

A Volume in the LIBRARY AND

INFORMATION SCIENCES SERIES

"This work addresses itself to WISE (World Information Synthesis Encyclopedia) or the idea of a "world brain." In the first part, the basic issues and priorities of information science and technology and their relation to social problems are discussed. The second section contains papers on the utilization of knowledge and information. The concluding section deals with the challenges of, and potential responses to, the use of knowledge for action in the future. . . There are many valuable insights and observations in this book, and it will be useful to a wide range of people, especially those working in information science." - Science, September 1976 1975,248 pp., $\$ 12.50 / £ 8.90$ ISBN: $0-12-417950-9$

\section{High-Level Computer Architecture edited by YAOHAN CHU}

"Several experts in the field discuss aspects of high-level language (HLL) computer architecture-computer structures conceived and designed for directly accepting and executing programs written in a high-level language. . Clear, relevant illustrations contribute a great deal to the text. ... Previously, HLL computer architecture has been covered primarily in journal, symposia, and report literature; this well-organized, thorough presentation of the subject will be a welcome addition to any computer science collection." —Choice, July/August 1976

1975, 273 pp., $\$ 29.50 / £ 20.95$

ISBN: $0-12-174150-8$

Send payment with order and save postage plus $50 \phi$ handling charge.

Prices are subject to change without notice.

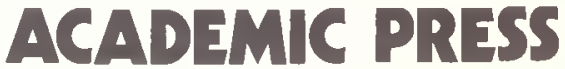

A Subsidiary of

Harcourt Brace Jovanovich, Publishers

111 FIFTH AVENUE, NEW YORK, N.Y. 10003

24-28 OVAL ROAD, LONDON NW1 7DX 